\title{
オランダの「人間工学判定の チェックリスト」についで
}

\author{
斉藤 良夫草, 増山英太 郎 ${ }^{* * *}$, 小木 和 孝 ${ }^{* *}$
}

\begin{abstract}
これは、オランダのア人間工学的基準ワーク・グループ』(Werkgroep Ergonomische Criteria)が 1969年に作成した 「人間工学判定チェックリスト』(Beoorde lings lijst Ergonomie, H. A.W. Klinkhamer 編) の紹介である.このワーク・グループは1958年にオランダの応用科学研究財団 (TNO) に 属する保健機構の労働医学研究会に F.H. Bonjer を長として設けられたものである. 産業医学者, 生 理学者, 心理学者, 工学者, 安全専門家, 体育生理学者などさまさまな分野の専門家が参加しており, このグルーブが作成したこのチェックリストも，きわめて特色のあるものになっている.
\end{abstract}

\section{はじめに}

国際的に知られた人間工学チェッ クリストとしては, 1964年に国際人 間工学会 (I.E.A.) が発表した「人 間工学的システム分析のためのチェ ックリスト」 (Ergonomics System Analysis Checklist) がある.この I.E.A.のチェックリストが作成さ れたときにも，このワークグループ の集めた資料が大いに活用されたと いう. その後， I.E.A.のチェック リストは各国で論議をよび，日本で も人間工学会のなかに委員会ができ 「作業の人間工学チェックリスト」 をその対案として1968年に刊行して いる.しかしこうした包括的リス トの場合には，チェックリスト使用 上からは設問が多すぎたり，判定に 迷ったり, 具体的事例に応用しにく かったりして，なかなか普及しな い.そうした反省にもとついて作ら れたのが,このチェックリストであ って, 実地調査を行なって構成して
いるだけあって，一見して実用的で ある.オランダ国内ではすでに 1,000 部以上売れている. 現在はオランダ 語版のみだが，近々に英訳がでる予 定のようである。

このチェックリストの目的も,さ まさまの作業状況や人間・機械系に ついて, 人間工学的検討を行ない, その改善をはかることにある。この チェックリストの「使用方法」の箇 所で強調されている「予防は治療よ り勝る」という諺が示しているよう にこのリストは，まず，将来の人間 ・機械系の設計, 製作のために役立 つものでなければいけないという意 図のもとに作成されている，そのた め,こまかい実務的知識は, むしろ チェックリスト本文からはずされて いて，それよりもシステム構成上の 人間工学的問題点がもれなく大づか みに洗いだされるように考えられて いる、それはこのリストの強味にな っているといってよく，1つのチェ ック対象について 2 時間たらずでチ

\footnotetext{
* 昭和 45 年 9 月 7 日受付

** 鉄道労㗢科学研究所 Railway Labour Science Research Institute

*** 製品科学研究所

Industrial Products Research Institute
}

エックを完了できるいう。

チェックリストは全部で19章から なる。

1. 空間 2 . 安全 3 . 有害物

4. 電離放射線 5 . 超短波と紫外 線 6. 気候 7. 騒音 8. 衝撃, 接触, 振動 9 . 作業域 10 . 姿勢と 静的負荷 11. 動的負荷 12. 微細 動作 13. 操作具, 道具 14 . 照明 15. 視覚情報 16. 聴覚情報 17 . 時間指示と選択指示の信号 18. 作 業時間と休您時間 19 . 生産性

\section{チェックの手順}

このチェックリストの最大の特徴 は, 項目チェックの手順である. 検 討すべき対象に応じて，必ずしも全 項目をチェックする必要がなく, 適 当に「スキップ」していくのである.

しかも, 必ず先へ先へとスキップし て, プログラム上は後もどりする要 がない，たとえば，後で紹介する

「騒音」の章は次頁の図 1 のような 構成になっている.

まず701の項目を検討し，それが NO とチェックされれば, 700 代の 項目はもうチェックする必要がなく すぐにつぎの 801 の項目に移ること 
が出来る，一方701が YES とチェッ クされれば，702 の項目にいき，そ れがさらにYESとチェックされれ ば703に……..ということになる. $705 \mid, 709,710$ などの四角で囲 まれた項目は，一般に，不適である と判定された状況を改善するために 考虑すべき対策がいくつか示されて いる項目で, 後述の手引書を参考に しながら，今までチェックした結果 からどのような対策を講ずべきか， またどのような対策が可能かなどを 検討するところである．Nとあるの は，その改善策，対策を講ずること により期待される効果, 実測結果な どをメモしなさいという意味であ る.

このように, 最初の項目からチェ ックが始まると, 後は答のYE S, NOに従って, 導かれるままにチェ ックリストのなかを「歩き趈る」こ とになる，原本は項目がすべて左ぺ 一ジに印刷され, 右ページは白紙に なっているので, 同じA 5 版の用紙 をそこにおいて，項目にたいする Y E S，NOを記入したり，考虑す べき対策などをメモしていく，用紙 は，1 章 1 枚ずつチェックできるよ うに, 職務名, 年月日, 記入者名な どの記入闌とともに構成されてい る.

\section{設問の構成と対策}

このチェックリストの設問につい
て, 編者の Klinkhamer は, 解説文 のなかでつぎのようにのべている.

「人間工学チェックリストのほと んどのものは, チェックされるため ではなく, 解答されるための質問群 から構成されている.解答は, その状 況の人間工学に関連した側面の記述 に役立つ.たとえば，1964年にドル トムントで提示された Ergonomics System Analysis Checklist の問B 156である：騒音のレベルと性状(周 波数スペクトル）はどうか？また 181 では：24 時間当りの推定全エネ ルギー消費はどの位か?このような 質問群からなるリストは記述的リス トとよばれ,これは, 記述にさいし て見落しのないようにするのに役立 つ.この種のチェックリストにたい する解答の助けがあり, 必要な人間 工学の知識の備えがあれば, 後に, どこで改良が出来るか決定すること が出来るようになるが，ぞのように してその改良が実現されるかをなお 見いださなければならない。

さて，質問からなる「記述的リス ト」にあっては, 量的解答を避ける ようにして設計され, その結果, 解 答はつねに単にYES S たはNOで あるようにすることが可能である. 結局のところわれわれは量には興味 がなく, 事柄が受けいれられるか否 かだけを知りたい、メーターや指示 計に抢けるように, 不必要な量的情

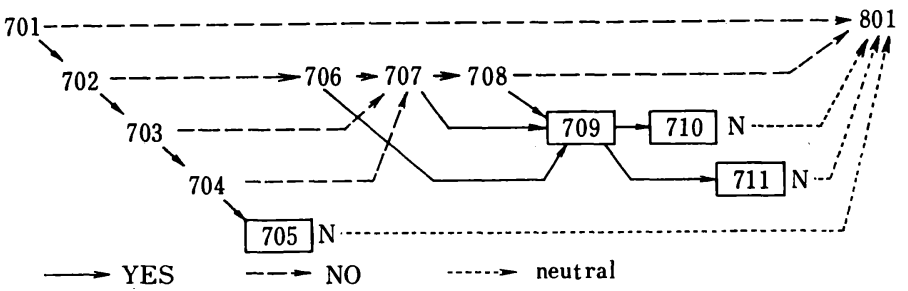

$\mathrm{N}$ : note dow $\mathrm{n} \quad \square$ "block", set of recommendations

図 1
報はあたえられるべきではない，そ の上,一群の Y E S-N O解答の取扱 いと処理の方がずっと容易である. 多くの場合, Y E S-NO解答のな かにすでに判断あるいは評価一受け いれられるか, 受けいれられないか 一がふくまれている．質問は，たと えばYE S はつねに受容可能を意味 しNOはこの特別の点が受容不可能 あるいは少くとも人間工学的にきわ どいことを意味するように設定する ことができる.このようにして設計 されたリストを，私は評価的リスト とよびたい。これは, 人間工学的な 見地から受容不可能かきわどい点を 見落さないようにするのに役立つ.

評価的リストの質問に答えるため には，標準を知っておかなければな らない.この標準についての知識は 存在するとも考えられるが，それに 代る方法は, 標準（あるいは複雑な 量的関係, グラフさえも）をリスト とともに示すことである. 標準は, 質問のなかにそのまま書かれるか， あるいは本を参照するなどの形式に よってか, いずれかによってくみこ むことができる.

簡単な Y E S-NO 質問の一例は ドルトムント・リストのA29である : 作業のレイアウトのために, 照明 水準の異なるいろいろな場所で作業 が行なわれているか？あるいはA42 では：両眼視は欠かせない要素か？ 評価的質問の例はA15である：作業 空間の床面は適当か? 標準をくみこ んだ質問はB 68 である.：ダイヤル を読みながら制御作業を行なう必要 があるとすれば, 読み距離は $70 \mathrm{~cm}$ 内外に限定されているか?

上述の要素のほか, チェックリス トは, 人間工学的欠点が見いだされ たなら，それを改善するための勧告 を含むこともある. 改善のための指 


\section{資 料}

示は，たとえばドルトムント・リス トの質問B21にみられる：負荷の度 合はつぎの方法で軽減できるか? 一操作する対象の重さの減少, 釣り合いのおもりの使用,一一電気, 水力ないし空気力装置の利用, コンペア，一クレーンか滑車か,

このように人間工学的欠点を改善 するための勧告をふくむりストを修 正的チェックリストとよぶことがで きる.

特別の目的, たとえば設計オフィ スだけのために立案されてきた人間 工学チェックリストのためには, 限 られた数の項目があれば十分であ る. 考えられるすべての状況向きの 普遍的リストは数百の項目からなり 考察中の事例には関係のない多くの 項目が含まれてしまう。このように 指示計やダイアルの人間工学は, こ のような装置が存在してもいないし 必要でもない状況に拈いては，不要 の積荷である.このような場合には 関連のない項目群を素通りする手段 を提供することが有用であろう．あ る項目から別の項目へと, 項目にた いする解答次第で, プログラム教示 におけるように指示されて動くシス テムをえがくことができる.ドルト ムント・リストでは,この原理はあ る程度 $\mathrm{A}$ 質問と $\mathrm{B}$ 質問をつかって適 用されている.この原理が論理的に 全面的に採用されると一一他の項目 への飛び石としてだけの役目で挿入 されている質問の助けをかりて— プログラム化されたチェックリスト がえられる。

チェックリストが一般に質問から 構成されなければならない必要は決 してない.チェックリストは，説明 文でも, 勧告でも, 命令であってさ えもよい.」

こうした考えにもとづいて，オラ
ンダの新しいチェックリストが作成 された.このチェックリストは， 1 人の人間 $\mathrm{P}$. (後出の訳文では「作業 者」とした）が登場し，その人につ いてチェックするという形式がとら れている、「1」人の人間についてチ エックしていくのが特色だと強調さ れている。ある 1 つの作業状況にさ まざまの職務をもった人がいる場合 には，その人たちについても同様に このチェックリストを用いて 1 人ず つ検討していかなければならないこ とになる.

\section{改 善 策}

不適と判定された項目の改善策は このリスト自体にもいくつか示され ているが，さらに詳しい内容を知り たいとき，また観測結果を基準值と 照合するときなどには「手引書」を 参考にすることになる。（項目によ っては，専門家の診断をあおぐよう に指定されていることもある). そ の手引書として指定されているのは Philips 社刊行のもので, Vademecum ergonomie voor de industrie (F. A. Kellerman, P. A. van Wely. P. J. Willems, 1963)「邦訳は小木和 孝訳 : 人間工学の指針, 人間と技術 社, 1967]である.そのほか, チェ ックリストでは，オランダ内外の約 200参考書を揭げて，このリストを 利用するときに参考にするようにす すめている.

前記の19章のうち，第 7 章と 13 章 の内容を紹介する．訳文中「手引書」 とあるのは, 上記の本をさし，ペー シは，邦訳のページを記入した。訳 は入手しえた英文の解説文にある一 部の項目の英訳を参考にした.

\section{第 7 章 騒 音}

（手引書 p. 22-24）

701 作業者は騒音の中で働いてい
る、騒音による障害が考えられ る.

$$
\text { はい } \rightarrow 702 \text { いいえ } \rightarrow 801
$$

702 騒音レベルは, 作業場の騒音の 最もひどい所で測定された。

はい $\rightarrow 706$ いいえ $\rightarrow 703$

703 作業場内はどこです，大声をは りあげないでも，1 $\mathrm{m}$ 以内で話 していることが理解できる.

はい $\rightarrow 707$ いいえ $\rightarrow 704$

704 専門家の推定では, 騒音は危険 限界以下にとどまっている.

はい $\rightarrow 707$ いいえ(また は疑わしい） $\rightarrow 705$

705

騒音レベルは, 専門家によっ て測定され，評価されなけれ ばならない, 騒音測定後, 再 びこの章に戻って, 706 から チェックすること. 705 の下 欄にメモをかくこと.

$\rightarrow 801$

706 測定された騒音レベルは, 危険 限界以下にとどまっている。 (手引書 p. 23).

はい $\rightarrow 707$ いいえ $\rightarrow 709$

707 作業者は, 騒音によって妨害さ れていると考えている。

はい $\rightarrow 709$ いいえ $\rightarrow 708$

708 作業者は, 騒音が明らかに作業 成果を減退させる作業（注意を 集中する検査，看視，かすかな 音を発見すること,など）に携 わっている. (手引書 p. 23).

$$
\text { はい } \rightarrow 709 \text { いいえ } \rightarrow 801
$$

709 つぎのような手段を考慮するこ と. (手引書 p. 24).

a ）騒音源を技術的に変更す る

b ）騒音源を遮蔽する

c ）騒音の激しい室を他の室 から隔離する 
d）騒音源を遠くにもってい

e ）床をつたわる騒音の伝導 を減少させる

f ）壁, 天井, 床などによる 音の吸収をよくする

g ）騒音にさらされる時間を 短縮する

これらの手段を出来るだけ講ず ること.

はい $\rightarrow 710$ いいえ $\rightarrow 711$

710709 にめした手段を講じても， 音の聞取りが困難なときは,つ ぎの特別な手段を講じるように しなければならない。

a ）作業者に保護具をつけさ せる

b ）騒首レベルを定期的に測 定する

c ）定期的に聴力検査をする

d）保護具をつけたとき，不 快感がないように，また作 業遂行を妨げないように留 意する

710 の下闌に，考慮しなけ ればならない手段を記すこと

$\rightarrow 801$

711

考虑しなければならない手段 やそれによってもたらされる 改善を, 711 の下闌に記すこ と.

\section{$\rightarrow 801$}

\section{第13章 操作具と道具}

（手引書 p. 55-70）

1301 作業者は,機械, 器具またはそ の他の装置の操作具を取扱う.

$$
\text { はい } \rightarrow 1302 \text { いいえ } \rightarrow 1319
$$

1302 つぎのような手段を考慮する こと. a ）どの操作具も, 偶然に動 作させられたり，また調整 位置がくるうことのないよ うにする（作業中または長 時間たつうちに押したり， ひっかけたりすることによ っ)

b ）作業者に要求されている 行動（力を入れるとか, 正 確な動作とかなど）にふさ わしい形式の操作具を選ふ (手引書 p. 55).

c ）操作具の動作方向がその 効果の方向と一致するよう にする（手引書 p. 76）

d ）操作具の動作方向がメ タ一や指示計の動作方向と 一致するようにする（手引 書 p. 75)

e ）操作力や抵抗を適度なも のにする（手引書 p. 56,58 60)

f）出力効果比が適切なもの を選ぶ

g ）操作具が常時ある位置に 止まっているときには，そ の中間位置に操作具がくる ことがないようにする（ス プリング, ラチェットなど によって)

h ）操作具間の距離を十分に とる（手引書 p. 55） 1302の下欄に，考虑しなけ ればならない手段を記すこと

$\rightarrow 1303$

1303 操作具は 1 つしかない.

はい $\rightarrow 1305 \rightarrow$ $\rightarrow$ いえ 1304

1304 つぎのような手段を考虑する こと.

a ）類似した装置は同一の場 所に,また同一の形式, 動
作方向にする（手引書 $\mathrm{p}$. 68)

b ）操作具の標識文字をはっ きりさせ，また良い色彩コ ードや他のコードをつかっ て，その操作具がわかるよ うにする（手引書 p. 70）

c）触れただけで，操作具が わかるようにする（手引書 p. 40)

d ）操作具の位置を作業者が 取扱う順序に並べる（手引 書 p. 69)

e ）操作具とそれと関係する 計器類とをまとめる（手引 書 p. 73,74 )

f）もっともよく使う操作具 を中央にもってくる

g ）パネル上の操作具の位置 を, 関係する作業過程のユ ニットと一致するようにす る (手引書 p. 68)

h ) 操作具と計器がふさわし い位置にくるようパネル上 にこの作業過程をレイアウ トする

i ）同一機能をもつ操作具は 同一場所にまとめる

j ）非常用または緊急用の操 作具（たとえば非常ブレー キ）は離しておきよく見 えるように，また作業者の 手がいつもとどくようにす る

k）いくつかの考えられる方 法のうち，最も良いものを 見出すために, 試験を行な 弓

1304の下欄に，考慮しなけ ればならない手段を記すこと

$\rightarrow 1305$

1305 作業者はペダルをつかう. 


\section{資 料}

はい $\rightarrow 1306$ いいえ $\rightarrow 1307$

1306 つぎのような手段を考虑する こと.

a ）作業者が立って作業をし ているならば, 坐って作業 するようにする．もしそう することが出来ないならば ペダルをやめるか，または せいぜい1つのペダルを断 続的に使うようにする

b ）ペダルの位置をできるだ け良いところにもっていく (手引書 p. 8)

c ）ペダルの大きさ，動き巾， 操作力および回転の中心位 置などを適度なものにする (手引書 p. $57,58,59$ ).

d) ペダルの数は 2 つ以上に しない

1306の下闌に，考虑しなけ ればならない手段を記すこと

1307 作業者は押しボタンやキイを 扱う。

はい $\rightarrow 1308$ いいえ $\rightarrow 1309$ 1308 つぎのような手段を考慮する こと.
a ）ボタンやキイが指先にた いして十分大きいようにす る (手引書 p.56)

b ）ボタンやキイの表面をさ らざらにまたはいくぶん円 形にする

c）スイッチオンやオフの位 置が一目でわかるようにす る，また，できれば，触れ ただけでもわかるようにす る

1308の下闌に，考虑しなけ ればならない手段を記するこ と
1309 作業者はトグルスイッチを操 作する.

はい $\rightarrow 1310$ いいえ $\rightarrow 1311$

1310 つぎのような手段を考虑する こと.

a ）大きさを望ましいものに する（手引書 p.60）

b）作業者がしばしば 1 つ以 上のスイッチを同時に操作 しなければならないときは 作業者の 1 回の操作で全部 のスイッチが動作するよう に，スイッチの位置をきめ る

1310の下闌に，考虑しなけ ればならない手段を記すこと

$$
\rightarrow 1311
$$

1311 作業者は回転ノブを取扱う。

はい $\rightarrow 1312$ いいえ $\rightarrow 1313$

1312 つぎのような手段を考虑する こと.

a ）大きさを望むしいものに する（手引書 p. 61, 62,63） b ）スケールの始点にストッ パーをもうける

いくつかの選択位置のあ るノブの場合は,

c）その位置の数が24を越え ないようにする

d）各選択位置間の角度を $15^{\circ}$ より小さくなく，また $40^{\circ}$ より大きくないように する

e ）各選択位置を示すノブの 目盛りのマークを互いに離 して,よく読めるようにす る

f ）スイッチ位置の全範囲を

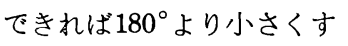
る
1312の下闌に考慮しなけれ ばならない手段を記すこと

$\rightarrow 1313$

1313 作業者はクランクを操作す る.

はい $\rightarrow 1314$ いいえ $\rightarrow 1315$ 1314 つぎのような手段を考虑する こと.

a ）大きさを望ましいものに する（手引書 p. 64）

b ）作業者が素速くまたは力 を入れて回さなければなら ないクランクの場合は，そ の握りが自分の軸のまわり に回転できるようにする

c）非常に細かい調節に用い るクランクの場合は, その 握りを固く固定する 1314の下欄に，考虑しなけ ればならない手段を記すこと

$\rightarrow 1315$

1315 作業者はハンドホイールを操 作する.

はい $\rightarrow 1316$ いいえ $\rightarrow 1317$ 1316 つぎのような手段を考慮する こと.

a ) 大きさを望ましいものに する（手引書 p.65）

b ）位置を望ましいものにし

手が十分届くようにする 1316の下闌に，考虑しなけ ればならない手段を記すこと $\rightarrow 1317$

1317 作業者はレバーを操作する. はい $\rightarrow 1318$ いいえ $\rightarrow 1319$ 1318 つぎのような手段を考虑する こと.

a ）レバーの動作距離は, 前 後 $35 \mathrm{~cm}$, 左右 $95 \mathrm{~cm}$ 以下に する 
b ）変位角度を $90^{\circ}$ 以下にす る

c ）変位角度 $30^{\circ}$ より大きい 場合は, 球状のグリップを 使う

d）作業者がレパーを正確に 調整しなければならないと きは，手首を支えるように する

e ）レバーを強い力で操作し なければならないときは, その力が望ましい值を越え ないようにする（手引書 p. 66,67)

f）強い力で操作するときは 身体に向って動作するよう に方向を選び，グリップは 作業者が立って操作すると きは，肩の高さにまた座
って操作するときは肘の高 さにする

1318の下闌に，考虑しなけ ればならない手段を記すこと

$$
\rightarrow 1319
$$

1319 作業者は道具を使う

$$
\text { はいー1320 いいえ } \rightarrow 1401
$$

1320 つぎのような手段を考虑する こと.

a ）道具の置く場所を指定す る

b ）適度な重さて，重心位置 の適当な道具を選ふ

c ）グリップの形をよくし, またその位置を適切にする

d ）道具の柄の長さを作業者 の行なう仕事に合せて, 作 業者がやりやすいようにす る e ）重い道具の場合は, 長時 間使用する作業者の苦痛を 和らげるような手段を考え る

f) 操作具 (スイッチ・ペン チの握りなど）のついた道 具の場合は，その動作方向 が期待される効果の方向と 一致するようにする

g ）その期待される効果にふ さわしい操作力にし，また 必要であれば，ロックを考 える

h ）道具の正しい使い方を作 業者に教しえる 1320の下闌に考慮しなけれ ばならない手段を記すこと

\section{発

近

刊

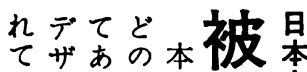

いイり上書

るン、少

関大に人战正

係学組間

のおみ因

テよ込子

キびんへ

ス短だ

大大ら間

にのよ工

洒るの人

と事で間人

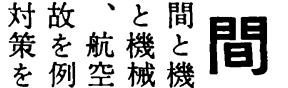

のに機を械

べ安、組の

て全車合共

あに輛せ存

るつ、が存

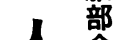

使被心学

い自場問

て動合題

の車のと

械

用服が学をを估

$\mathbf{B}$
5

問、安安

の

き科中被

るを心服

題産全れ

点業のて

を職問い亥

よはと構

うじし成

にめての

配、編な

慮被集か

さ服しに

あ場題る

げなを折

全

そにじ本

のおた書坒

評けもは江

大需標・人 行

こ報生にしる二

比準人男口告体な文一万 综化体女主に書計つ本献 $\bigcirc$ 国 基/ののな資に测た書の○博 撉作経計内料基部。を一○の 污業年測容をづ会改全つ年記 道的值新いが訂面に後含 ペ変/測たて発に的本に念 |化男定に計表あに書残事 ス・女点付計した改の業 、体生紧測たう訂初たの 高表徒測加項生てし版め一 Bさ面の定之目体は、がの環 5 の積計項てお計、普選夕と 判基ほ测目編ば测先及ばイし 準か值お集びのに版れムて 1 ほ//よし测標日をた力 4 牲重びた定準本発。プ今 0 体心测も点化人行こ七日 0 計・定のをの間すれルの 円測重法で統た王るをに文 値量・あ一め学こ記入明 の比成る。しの会と念れを

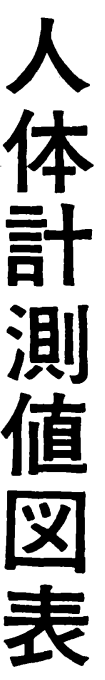

干114 東京都北区西ヶ原 1-40-10古河第 2 マンション209 電話915-5334振替東京 95039 